\title{
Maternal Thyroid Dysfunction and Risk of Neonatal Stroke
}

\author{
Ahmed R.G* \\ Division of Anatomy and Embryology, Zoology Department, Faculty of Science, Beni-Suef University, Beni- \\ Suef, Egypt
}

*Corresponding Author: Ahmed R.G, Division of Anatomy and Embryology, Zoology Department, Faculty of Science, Beni-Suef University, Beni-Suef, Egypt. Email: ahmedragab08@gmail.com

\section{LETTER TO EDITOR}

During the gestational period, steady increase in the levels of maternal thyroid hormones (THs; thyroxine (T4) and 3,5,3'-triodothyronine (T3))isessential for the regular development during the gestational and suckling periods(Elbakry et al., 2010; Ahmed, 2011, 2012a,b, 2013, 2014, 2015a-c, 2016a-d, 2017a-v\& 2018a-i; Ahmed et al., 2010, 2013a,b, 2014, 2015a,b \& 2018a,b; Ahmed and Incerpi, 2013; Van Hercket al., 2013; Ahmed and El-Gareib, 2014,Incerpi et al., 2014; Candelotti et al., 2015; De Vito et al., 2015; El-Ghareeb et al., 2016; Ahmed and ElGareib, 2017) in particular the neuro-vascular system (Ahmed, 2017d-e \& 2018h,i).THs can bind their receptor on integrin $\alpha \mathrm{VB3}$ to regulate the extracellular matrix proteins, brain connectivity, and synaptic plasticity (Cheng et al., 2010; Ambrosius et al. 2017a,b). In addition, THs can regulate the systolic and diastolic cardiac function, increase the left ventricular (LV) contractile function, and decrease the systemic vascular resistance (SVR) (Klein and Ojamaa, 2001a,b).

On the other hand, the reduction in the levels of free T3 (FT3) might increase the risk of stroke and decrease the outcome (Ambrosius et al., 2011; Neidert et al., 2011; Filimonov et al., 2017). Also, Sullivan and Sage (2004) and Ambrosius et al. (2017a, b) reported that the elevation in the levels of free T4 (FT4) andthe reduction in the levels of thyroid-stimulating hormone (TSH) can increase the ischemic stroke patho-physiology. In addition, the reduction in the levels of TSH in an elderly population can cause heart failure, atrial fibrillation (AF), coronary artery disease (CAD), and coronary heart disease (CHD) (Bauer et al., 1998; Biondi and Cooper, 2008; Rodondi et al., 2010; Collet et al., 2012; Taylor et al., 2013; Chaker et al.,
2016).This is a main cause of morbidity and mortality. On the contrary, Taylor et al. (2013) observed that the elevation in the levels of TSH and the reduction in the levels of FT4 can cause several cardiovascular problems. As well, the disturbances in the functions of thyroid glands can increase the possibility of numerous cardiovascular disorders such as atherosclerosis (Cappola and Ladenson, 2003), dyslipidemia (Duntas, 2002), and hypertension (Nagasaki et al., 2006). These abnormal disordershave also been noticed in patients of subclinical thyroid disorders (Hak et al., 2000; Iqbal et al., 2006; Asvold et al., 2007a,b).These symptoms with the primary haemorrhage, closed vessel ischaemia (venous and/or arterial), global forebrain ischaemiacan cause the fetal or neonatal stroke (Raju et al., 2007; Govaert, 2009), fracture risk and cognitive disorders (Cappola et al., 2014; Blum et al., 2015).On the other hand, the administration of THs has been establishedto confer neuroprotection in stroke (Bettendorf et al., 2000; Genovese et al., 2013; Sadana et al., 2015; Suda et al., 2016) on account of THs may have neurotropic effects during stroke.

From the aforementionedresults, it can be concluded that the variations in gestational THs (hypothyroidism or hyperthyroidism) may lead to long-lastingimpairment in the neonatal neurovascular and cardiovascular systems. These conditionsmayinterrupt the neonatal cognitive functions. Hence, brain imaging with the management of maternal thyroid hormonesmay diminish the risk of neonatal stroke. Additional studies are needed to investigate whether the regulation of maternal thyroid autoimmunity, hormonal supplementation or antagonism mayenhance the functional outcome of neonatal stroke. 


\section{REFERENCES}

[1] Ahmed, O.M., Abd El-Tawab, S.M., Ahmed, R.G., 2010. Effects of experimentally induced maternal hypothyroidism and hyperthyroidism on the development of rat offspring: I- The development of the thyroid hormonesneurotransmitters and adenosinergic system interactions. Int. J. Dev. Neurosci. 28, 437-454.

[2] Ahmed, O.M., Abd El-Tawab, S.M., Ahmed, R.G., 2010. Effects of experimentally induced maternal hypothyroidism and hyperthyroidism on the development of rat offspring: I- The development of the thyroid hormonesneurotransmitters and adenosinergic system interactions. Int. J. Dev. Neurosci. 28, 437454.

[3] Ahmed, O.M., Ahmed, R.G., 2012. Hypothyroidism. In A New Look At Hypothyroidism. Dr. D. Springer (Ed.), ISBN: 978-953-51-0020-1), In Tech Open Access Publisher, Chapter 1, pp. 1-20.

[4] Ahmed, O.M., Ahmed, R.G., El-Gareib, A.W., El-Bakry, A.M., Abd El-Tawaba, S.M., 2012. Effects of experimentally induced maternal hypothyroidism and hyperthyroidism on the development of rat offspring: II-The developmental pattern of neurons in relation to oxidative stress and antioxidant defense system. Int. J. Dev. Neurosci. 30, 517-537.

[5] Ahmed, O.M., El-Gareib, A.W., El-bakry, A.M., Abd El-Tawab, S.M., Ahmed, R.G., 2008. Thyroid hormones states and brain development interactions. Int. J. Dev. Neurosci. 26(2), 147-209. Review.

[6] Ahmed, R.G., 2011. Perinatal 2, 3, 7, 8tetrachlorodibenzo-p-dioxin exposure alters developmental neuroendocrine system. Food Chem. Toxicology, 49, 1276-1284.

[7] Ahmed, R.G., 2012a. Maternal-newborn thyroid dysfunction.In the Developmental Neuroendocrinology, pp. 1-369. Ed R.G. Ahmed. Germany: LAP LAMBERT Academic Publishing GmbH \& Co KG.

[8] Ahmed, R.G., 2012b. Maternal-fetal thyroid interactions, Thyroid Hormone, Dr. N.K. Agrawal (Ed.), ISBN: 978-953-51-0678-4, In Tech Open Access Publisher, Chapter 5, pp. 125-156.

[9] Ahmed, R.G., 2013. Early weaning PCB 95 exposure alters the neonatal endocrine system: thyroid adipokine dysfunction. J. Endocrinol. 219 (3), 205-215.

[10] Ahmed, R.G., 2014. Editorial: Do PCBs modify the thyroid-adipokine axis during development? Annals Thyroid Res. 1(1), 11-12.

[11] Ahmed, R.G., 2015a. Chapter 1: Hypothyroidism and brain development. In advances in hypothyroidism treatment. Avid
Science Borsigstr.9, 10115 Berlin, Berlin, Germany. Avid Science Publications level 6, Melange Towers, Wing a, Hitec City, Hyderabad, Telangana, India. pp. 1-40.

[12] Ahmed, R.G., 2015b. Hypothyroidism and brain developmental players. Thyroid Research J. 8(2), 1-12.

[13] Ahmed, R.G., 2015c. Editorials and Commentary: Maternofetal thyroid action and brain development. J. of Advances in Biology; 7(1), 1207-1213.

[14] Ahmed, R.G., 2016a. Gestational dexamethasone alters fetal neuroendocrine axis. Toxicology Letters, 258, 46-54.

[15] Ahmed, R.G., 2016b. Neonatal polychlorinated biphenyls-induced endocrine dysfunction. Ann. Thyroid. Res. 2 (1), 34-35.

[16] Ahmed, R.G., 2016c. Maternal iodine deficiency and brain disorders. Endocrinol. Metab.Syndr.5, 223. http://dx.doi.org /10.4172/ 2161-1017.1000223.

[17] Ahmed, R.G., 2016d. Maternal bisphenol A alters fetal endocrine system: Thyroid adipokine dysfunction. Food Chem. Toxicology, 95, 168-174.

[18] Ahmed, R.G.,2017a. Developmental thyroid diseases and GABAergic dysfunction. EC Neurology 8.1, 02-04.

[19] Ahmed, R.G., 2017b. Hyperthyroidism and developmental dysfunction.Arch Med. 9, 4.

[20] Ahmed, R.G.,2017c. Anti-thyroid drugs may be at higher risk for perinatal thyroid disease. EC Pharmacology and Toxicology 4.4, 140-142.

[21] Ahmed, R.G.,2017d. Perinatal hypothyroidism and cytoskeleton dysfunction. Endocrinol MetabSyndr 6, 271.doi:10.4172/2161-1017. 1000271

[22] Ahmed, R.G.,2017e. Developmental thyroid diseases and monoaminergic dysfunction. Advances in Applied Science Research 8(3), 01-10.

[23] Ahmed, R.G.,2017f.Hypothyroidism and brain development.J. Anim Res Nutr.2(2), 13.

[24] Ahmed, R.G.,2017g. Antiepileptic drugs and developmental neuroendocrine dysfunction: Every why has A Wherefore.Arch Med 9(6), 2.

[25] Ahmed, R.G.,2017h. Gestational prooxidantantioxidant imbalance may be at higher risk for postpartum thyroid disease. Endocrinol MetabSyndr 6, 279. doi:10.4172/2161-1017. 1000279.

[26] Ahmed, R.G.,2017i. Synergistic actions of thyroid-adipokines axis during development. Endocrinol MetabSyndr 6, 280.doi:10.4172/ 2161-1017.1000280.

[27] Ahmed, R.G.,2017j. Thyroid-insulin dysfunction during development. International Journal of Research Studies in Zoology 3(4), 
73-75. DOI: http://dx.doi.org/10.20431/2454941X.0304010.

[28] Ahmed, R.G.,2017k. Developmental thyroid diseases and cholinergic imbalance. International Journal of Research Studies in Zoology 3(4), 70-72. DOI: http:// dx.doi.org/ 10.20431/2454-941X.0304009.

[29] Ahmed, R.G.,20171. Thyroid diseases and developmental adenosinergic imbalance.Int $\mathbf{J}$ ClinEndocrinol 1(2), 053-055.

[30] Ahmed, R.G.,2017m. Maternal anticancer drugs and fetal neuroendocrine dysfunction in experimental animals. EndocrinolMetabSyndr 6, 281.doi:10.4172/2161-1017.1000281.

[31] Ahmed, R.G.,2017n. Letter: Gestational dexamethasone may be at higher risk for thyroid disease developing peripartum. Open Journal Of Biomedical \& Life Sciences (Ojbili) 3(2), 01-06.

[32] Ahmed, R.G.,2017o. Deiodinases and developmental hypothyroidism. EC Nutrition 11.5, 183-185.

[33] Ahmed, R.G.,2017p. Maternofetal thyroid hormones and risk of diabetes. Int. J. of Res. Studies in Medical and Health Sciences 2(10), 18-21.

[34] Ahmed, R.G.,2017r. Association between hypothyroidism and renal dysfunctions. International Journal of Research Studies in Medical and Health Sciences 2(11), 1-4.

[35] Ahmed, R.G.,2017s.Maternal hypothyroidism and lung dysfunction. International Journal of Research Studies in Medical and Health Sciences 2(11), 8-11.

[36] Ahmed, R.G.,2017t.Endocrine disruptors; possible mechanisms for inducing developmental disorders.International journal of basic science in medicine (IJBSM)2(4), 157160.

[37] Ahmed, R.G.,2017u. Maternal thyroid hormones trajectories and neonatal behavioral disorders. ARC Journal of Diabetes and Endocrinology 3(2), 18-21.

[38] Ahmed, R.G.,2017v. Maternal thyroid dysfunction and neonatal cardiac disorders. Insights Biol Med. 1, 092-096.

[39] Ahmed, R.G.,2018a. Maternal hypothyroidism and neonatal testicular dysfunction. International Journal of Research Studies in Medical and Health Sciences 3(1), 8-12.

[40] Ahmed, R.G.,2018b. Maternal thyroid disorders and bone maldevelopment: Are you ready to take risks for your offspring? J Pharma PharmaSci (JPPS) in press. DOI: 10.29011/ 2574-7711. 100058.

[41] Ahmed, R.G.,2018c. Non-genomic actions of thyroid hormones during development. App ClinPharmacolToxicol: ACPT-108. DOI: 10.29011/ACPT-109. 100008.
[42] Ahmed, R.G.,2018d. Maternal thyroid function and placental hemodynamics. ARC Journal of Animal and Veterinary Sciences 4(1), 9-13. DOI: http://dx.doi.org/10.20431/2455-2518. 04 01002.

[43] Ahmed, R.G.,2018e. Interactions between thyroid and growth factors during development. ARC Journal of Diabetes and Endocrinology 4(1), 1-4. DOI: http://dx.doi.org/ 10.20431/ 2455-5983.0401001.

[44] Ahmed, R.G.,2018f. Maternal thyroid hormones and neonatal appetite. ARC Journal of Nutrition and Growth 4(1), 18-22. DOI: http://dx.doi.org/10.20431/2455-2550.0401005.

[45] Ahmed, R.G.,2018g. Genomic actions of thyroid hormones during development. ARC Journal of Diabetes and Endocrinology 4(1), 58. DOI: http://dx.doi.org/10.20431/2455-5983. 0401002 .

[46] Ahmed, R.G.,2018h. Dysfunction of maternal thyroid hormones and psychiatric symptoms.American Research Journal of Endocrinology. 2(1), 1-6.

[47] Ahmed, R.G.,2018i. Is there a connection between maternal hypothyroidism and developing autism spectrum disorders?ARC Journal of Neuroscience 3(1), In Press. DOI: http://dx.doi.org/10.20431/2456-057X.030100 2 .

[48] Ahmed, R.G., Abdel-Latif, M., Ahmed F., 2015a.Protective effects of GM-CSF in experimental neonatal hypothyroidism. International Immunopharmacology 29, 538543.

[49] Ahmed, R.G., Abdel-Latif, M., Mahdi, E., ElNesr, K., 2015b. Immune stimulation improves endocrine and neural fetal outcomes in a model of maternofetal thyrotoxicosis. Int. Immunopharmacol. 29, 714-721.

[50] Ahmed, R.G., Davis, P.J., Davis, F.B., De Vito, P., Farias, R.N., Luly, P., Pedersen, J.Z., Incerpi, S., 2013a. Nongenomic actions of thyroid hormones: from basic research to clinical applications. An update. Immunology, Endocrine \& Metabolic Agents in Medicinal Chemistry, 13(1), 46-59.

[51] Ahmed, R.G., El-Gareib, A.W. 2014.Lactating PTU exposure: I- Alters thyroid-neural axis in neonatal cerebellum. Eur. J. of Biol. and Medical Sci. Res. 2(1), 1-16.

[52] Ahmed, R.G., El-Gareib, A.W., 2017.Maternal carbamazepine alters fetal neuroendocrinecytokines axis. Toxicology 382, 59-66.

[53] Ahmed, R.G., El-Gareib, A.W., Incerpi, S., 2014. Lactating PTU exposure: II- Alters thyroid-axis and prooxidant-antioxidant balance in neonatal cerebellum. Int. Res. J. of Natural Sciences 2(1), 1-20. 
[54] Ahmed, R.G.,El-Gareib, A.W., Shaker, H.M., 2018a.Gestational 3,3',4,4',5-pentachloro biphenyl (PCB 126) exposure disrupts fetoplacental unit: Fetal thyroid-cytokines dysfunction. Life Sciences 192, 213-220.

[55] Ahmed, R.G., Incerpi, S., 2013. Gestational doxorubicin alters fetal thyroid-brain axis. Int. J. Devl. Neuroscience 31, 96-104.

[56] Ahmed, R.G., Incerpi, S., Ahmed, F., Gaber, A., 2013b. The developmental and physiological interactions between free radicals and antioxidant: Effect of environmental pollutants. J. of Natural Sci. Res. 3(13), 74-110.

[57] Ahmed, R.G.,Walaa G.H., Asmaa F.S., 2018b.Suppressive effects of neonatal bisphenol A on the neuroendocrine system.Toxicology and Industrial Health Journal (in press).

[58] Ambrosius, W., Kazmierski, R., Gupta, V., Warot, A.W., Adamczewska-Kocialkowska, D., Blazejewska, A., 2011. Low free triiodothyronine levels are related to poor prognosis in acute ischemic stroke. ExpClinEndocrinol Diabetes 119(3), 139-43.

[59] Ambrosius, W., Michalak, S., Kazmierski, R., Lukasik, M., Andrzejewska, N., Kozubski, W., 2017b. The association between serum matricellularprotein: secreted protein acidic and rich in cysteine-like 1 levels and ischemic stroke severity. J Stroke Cerebrovasc Diseases pii:S1052- 3057(17)30545-1.

[60] Ambrosius, W., Rosinska, J., Michalak, S., Lukasik, M., Kazmierski, R., Kozubski, W., 2017a. Free thyroxine and TSH interact with secreted protein acidic and rich in cysteine-like 1 in ischemic stroke. Neurologia I NeurochirurgiaPolska, XX-XXXX.

[61] Asvold, B.O., Bjoro, T., Nilsen, T.I., Vatten, L.J., 2007a. Association between blood pressure and serum thyroid-stimulating hormone concentration within the reference range: a population-based study. J ClinEndocrinolMetab. 92, 841-845.

[62] Asvold, B.O., Vatten, L.J., Nilsen, T.I., Bjoro, T., 2007b. The association between TSH within the reference range and serum lipid concentrations in a population-based study. The HUNT Study. Eur J Endocrinol.156, 181-186.

[63] Bauer, D.C., Ettinger, B., Browner, W.S., 1998. Thyroid functions and serum lipids in older women: a population-based study. Am J Med. 104, 546-551.

[64] Bettendorf, M., Schmidt, K.G., Grulich-Henn, J., Ulmer, H.E., Heinrich, U.E., 2000. Triiodothyronine treatment in children after cardiac surgery: a double-blind, randomised, placebo-controlled study, Lancet 356, 529-534.
[65] Biondi, B., Cooper, D.S., 2008. The clinical significance of subclinical thyroid dysfunction. Endocrine Reviews 29, 76-131.

[66] Blum, M.R., Bauer, D.C., Collet, T.H., Fink, H.A., Cappola, A.R., da Costa, B.R., Wirth, C.D., Peeters, R.P., 2015. Thyroid Studies C. Subclinical thyroid dysfunction and fracture risk: a meta-analysis. JAMA 313, 2055-2065.

[67] Candelotti, E., De Vito, P., Ahmed, R.G., Luly, P., Davis, P.J., Pedersen, J.Z., Lin, H-Y., Incerpi, I., 2015. Thyroid hormones crosstalk with growth factors: Old facts and new hypotheses. Immun., Endoc.\&Metab. Agents in Med. Chem., 15, 71-85.

[68] Cappola, A.R., Arnold, A.M., Wulczyn, K., Carlson, M., Robbins, J., Psaty, B.M., 2014.Thyroid Function in the Euthyroid Range and Adverse Outcomes in Older Adults.J ClinEndocrinolMetab. jc20143586.

[69] Cappola, A.R., Ladenson, P.W., 2003. Hypothyroidism and atherosclerosis.J ClinEndocrinol Metab.88, 2438-2444.

[70] Chaker, L., Baumgartner, C., den Elzen, W.P.J., Collet, T-H., Ikram, M.A., Blum, M.R., Dehghan, A., Drechsler, C., 2016. Thyroid Function within the Reference Range and the Risk of Stroke: An Individual Participant Data Analysis. J ClinEndocrinolMetab 1-14.

[71] Cheng, S.Y., Leonard, J.L., Davis, P.J., 2010. Molecular aspects of thyroid hormone actions.Endocr Rev 31(2), 139-70.

[72] Collet, T.H., Gussekloo, J., Bauer, D.C., den Elzen, W.P., Cappola, A.R., Balmer, P., Iervasi, G., Asvold, B.O., 2012. Thyroid Studies C. Subclinical hyperthyroidism and the risk of coronary heart disease and mortality. Arch Intern Med. 172, 799-809.

[73] De Vito, P., Candelotti, E., Ahmed, R.G., Luly, P., Davis, P.J., Incerpi, S., Pedersen, J.Z., 2015.Role of thyroid hormones in insulin resistance and diabetes.Immun., Endoc.\&Metab. Agents in Med. Chem., 15, 8693.

[74] Duntas, L.H., 2002. Thyroid disease and lipids. Thyroid. 12, 287-293.

[75] El-bakry, A.M., El-Ghareeb, A.W.,Ahmed, R.G., 2010.Comparative study of the effects of experimentally-induced hypothyroidism and hyperthyroidism in some brain regions in albino rats.Int. J. Dev. Neurosci. 28, 371-389.

[76] El-Ghareeb, A.A., El-Bakry, A.M., Ahmed, R.G., Gaber, A., 2016.Effects of zinc supplementation in neonatal hypothyroidism and cerebellar distortion induced by maternal carbimazole. Asian Journal of Applied Sciences 4(04), 1030-1040.

[77] Filimonov, D., Yevtushenko, S., Yevtushenko, I., Trubnikova, N., Belotserkovskaya, M., Savoskin, M., Eresko, A., Muratov, A., Gusac, 
V.K., 2017. The relationship between thyroid metabolism and the stroke severity and outcome with a focus on neuroprotection: Clinical and experimental study. Abstracts / Journal of the Neurological Sciences 381, 413. doi:10.1016/j.jns.2017.08.3379.

[78] Genovese, T., Impellizzeri, D., Ahmad, A., Cornelius, C.,Campolo, M.,Cuzzocrea, S., Esposito, E., 2013.Post-ischaemic thyroid hormone treatment in a rat model of acute stroke, Brain Res. 1513, 92-102.

[79] Govaert, P., 2009. Prenatal stroke. Seminars in Fetal \& Neonatal Medicine 14, 250-266.

[80] Hak, A.E., Pols, H.A., Visser, T.J., Drexhage, H.A., Hofman, A., Witteman, J.C., 2000. Subclinical hypothyroidism is an independent risk factor for atherosclerosis and myocardial infarction in elderly women: the Rotterdam Study. Ann Intern Med.132, 270-278.

[81] Incerpi, S., Hsieh, M-T., Lin, H-Y., Cheng, GY., De Vito, P., Fiore, A.M., Ahmed, R.G., Salvia, R., Candelotti, E., Leone, S., Luly, P., Pedersen, J.Z., Davis, F.B., Davis, P.J., 2014. Thyroid hormone inhibition in L6 myoblasts of IGF-I-mediated glucose uptake and proliferation: new roles for integrin $\alpha \mathrm{v} \beta 3$. Am. J. Physiol. Cell Physiol. 307, C150-C161.

[82] Iqbal, A., Figenschau, Y., Jorde, R., 2006. Blood pressure in relation to serum thyrotropin: The Tromso study. Journal of Human Hypertension. 20, 932-936.

[83] Klein, I., Ojamaa, K., 2001a. Thyroid hormone: targeting the vascular smoothmuscle cell. Circulation Res.88, 260-261.

[84] Klein, I., Ojamaa, K., 2001b.Thyroid hormone and the cardiovascular system.N Engl J Med. 344, 501-509.

[85] Nagasaki T, Inaba M, Kumeda Y, Hiura Y, Shirakawa K, Yamada S, Henmi Y, Ishimura E, Nishizawa Y., 2006. Increased pulse wave velocity in subclinical hypothyroidism. J ClinEndocrinolMetab. 91, 154-158.
[86] Neidert, S., Katan, M., Schuetz, P., Fluri, F., Ernst, A., Bingisser, R., 2011.Anterior pituitary axis hormones and outcome in acute ischaemic stroke.J Intern Med 269(4), 420-32.

[87] Raju, T.N.K., Nelson, K.B., Ferriero, D., Lynch, J., 2007. The NICHD-NINDS perinatal stroke workshop participants. Perinatal stroke: summary of a workshop sponsored by NICHD and NINDS on classification, challenges and opportunities. Pediatrics 120, 609-16.

[88] Rodondi, N., den Elzen, W.P., Bauer, D.C., Cappola, A.R., Razvi, S., Walsh, J.P., Asvold, B.O., Iervasi, G., 2010. Thyroid Studies C. Subclinical hypothyroidism and the risk of coronary heart disease and mortality.JAMA. 304, 1365-1374.

[89] Sadana, P., Coughlin, L., Burke, J., Woods, R.,Mdzinarishvili, A., 2015. Anti-edema action of thyroid hormone in MCAO model of ischemic brain stroke: possible association with AQP4 modulation, J. Neurol. Sci. 354, 37-45.

[90] Suda, S., Muraga, K., Kanamaru, T., Okubo, S., Abe, A., Aoki, J., Suzuki, K., Sakamoto, Y., 2016. Low free triiodothyronine predicts poor functional outcome after acute ischemic stroke. Journal of the Neurological Sciences 368, 8993.

[91] Sullivan, M.M., Sage, E.H., 2004. Hevin/SC1, a matricellular glycoprotein and potential tumor-suppressor of the SPARC/ BM40/Osteonectin family.Int J Biochem Cell Biol 36, 991-6.

[92] Taylor, P.N., Razvi, S., Pearce, S.H., Dayan, C.M., 2013. Clinical review: A review of the clinical consequences of variation in thyroid function within the reference range. $\mathbf{J}$ ClinEndocrinolMetab. 98, 3562-3571.

[93] Van Herck, S.L.J., Geysens, S., Bald, E., Chwatko, G., Delezie, E., Dianati, E., Ahmed, R.G., Darras, V.M., 2013.Maternal transfer of methimazole and effects on thyroid hormone availability in embryonic tissues.Endocrinol. 218, 105-115.

Citation: Ahmed R.G. Maternal Thyroid Dysfunction and Risk of Neonatal Stroke. ARC Journal of Animal and Veterinary Sciences. 2018; 4(1):22-26. doi: dx.doi.org/ 10.20431/2455-2518.0401004.

Copyright: (c) 2018 Authors. This is an open-access article distributed under the terms of the Creative Commons Attribution License, which permits unrestricted use, distribution, and reproduction in any medium, provided the original author and source are credited. 